\title{
Nystagmus in non-alcoholic Wernicke encephalopathy
}

\author{
Kojiro Ikeda, Hiroyuki Yano, Tetsushi Higa, Mitsuyo Kinjo
}

Department of Medicine Okinawa Chubu Hospital, Uruma, Okinawa, Japan

\section{Correspondence to} Dr Mitsuyo Kinjo; kinjomitsuyo@gmail.com

Accepted 4 February 2021
Check for updates

(C) BMJ Publishing Group Limited 2021. No commercial re-use. See rights and permissions. Published by BMJ.

To cite: Ikeda $\mathrm{K}$, Yano $\mathrm{H}$, Higa T, et al. BMJ Case Rep 2021;14:e241130. doi:10.1136/bcr-2020241130

\section{DESCRIPTION}

A 46-year-old woman with no history of alcohol use presented with blurry vision and difficulty walking. She reported that her eyes were unfocused when texting messages on iPhone. She had been eating only ice cream for three months, felt extremely fatigued and lost $3 \mathrm{~kg}$ after her mother's death. She could not keep herself upright and sought medical attention. Her medical and family history was unremarkable. She did not smoke or use illicit drugs.

Her height was $153 \mathrm{~cm}$ and weight was $38.8 \mathrm{~kg}$. Her temperature was $37.8^{\circ} \mathrm{C}$, blood pressure was $106 / 73 \mathrm{~mm} \mathrm{Hg}$, pulse was regular at 110 beats per minute, respirations were 20 per minute and oxygen saturation was $97 \%$ on ambient air. She was alert and oriented to time, place and person; appeared cachexic with masked facies, and was barely responsive to questions. Neurological examination revealed impaired eye movements with horizontal nystagmus, spontaneous upbeat nystagmus and upgaze-evoked spontaneous upbeat nystagmus (video 1). Strength and sensation to light touch were intact. Deep tendon reflexes were symmetrical. Cerebellar dysmetria were absent. Romberg testing could not be performed. Physical examination was otherwise unremarkable

Laboratory studies showed normal electrolyte levels, kidney and liver function, total protein, albumin and haemoglobin A1c. Complete blood count showed mild leucocytosis and increased haematocrit. Thyroid function tests, serum levels of vitamin $B_{12}$, folic acid, copper and zinc were normal. Thiamine level was measured. Brain MRI revealed high intensity in bilateral thalami on diffusionweighted imaging, T2-weighted images and fluidattenuated inversion recovery (FLAIR) images (figure 1). Ocular dysfunction, gate disturbance and MRI findings suggested Wernicke encephalopathy (WE). Intravenous administration of thiamine ameliorated her symptoms, improved the nystagmus and she became expressive in 2 weeks. The patient

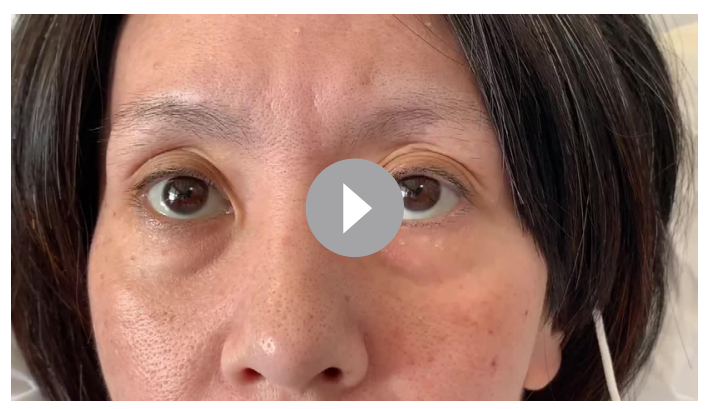

Video 1 Impaired eye movements with horizontal nystagmus and upgaze-evoked spontaneous upbeat nystagmus.

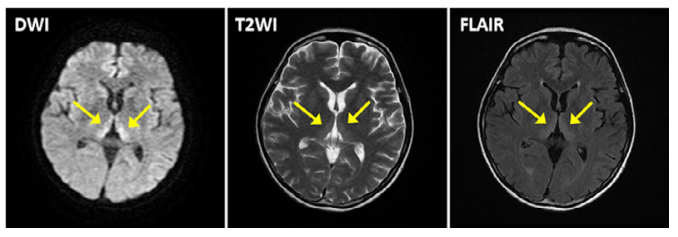

Figure 1 Brain MRI revealed high intensity in bilateral thalami on DWI, T2WI and FLAIR. DWI, diffusionweighted imaging; FLAIR, fluid-attenuated inversion recovery; T2WI, T2-weighted image.

was discharged ambulatory on day 19 . The vitamin $\mathrm{B}_{1}$ level before the treatment turned out to be low at $17.0 \mathrm{ng} / \mathrm{mL}$ (reference range 21.3-81.9).

WE is a neurological disorder and associated with thiamine deficiency. Thiamine, also known as vitamin $B_{1}$, is a coenzyme for several enzymes in organic pathways and plays a key role in cerebral energy homoeostasis. ${ }^{1}$ Deficiency of thiamine causes neurological complications and develops in chronic alcoholism, severe malnutrition, hyperemesis gravidarum, intestinal obstruction, gastrointestinal surgery (bariatric surgery, gastrectomy and colectomy), cancer chemotherapy, haemodialysis and malignant diseases. ${ }^{23}$ In this case, eating ice cream exclusively for 3 months may have exacerbated thiamine deficiency because glucose oxidation decreases thiamine levels. ${ }^{1}$

The clinical triad seen in WE includes altered mental status, ophthalmoplegia and gait ataxia, although the presence of all features is uncommon. ${ }^{1}$ Non-alcoholic WE may demonstrate a more acute presentation than alcoholic $\mathrm{WE},{ }^{4}$ and ocular dysfunction tends to be the first presentation in non-alcoholic WE. ${ }^{5}$ Horizontal gaze-evoked

\section{Learning points}

Wernicke encephalopathy (WE) develops in chronic alcoholism, severe malnutrition, hyperemesis gravidarum, intestinal obstruction, gastrointestinal surgery (bariatric surgery, gastrectomy and colectomy), cancer chemotherapy, haemodialysis and malignant diseases.

- Non-alcoholic WE may demonstrate a more acute presentation than alcoholic WE, and ocular dysfunction tends to be the first presentation in non-alcoholic WE.

- Characteristic features of MRI include increased intensity of bilateral medial thalami, the mammillary bodies, tectal plate, periaqueductal area and around the third ventricle on $\mathrm{T} 2$ and fluid-attenuated inversion recovery images. 
nystagmus is the typical ocular manifestation of WE, and vertical gaze-evoked nystagmus is less common. ${ }^{6}$

MRI is helpful in diagnosing WE. Characteristic features of MRI include increased intensity of bilateral medial thalami, the mammillary bodies, tectal plate, periaqueductal area and around the third ventricle on T2 and FLAIR images.

WE is a medical emergency and under-recognised especially in non-alcoholic patients. Prolonged neurological impairment such as Korsakoff syndrome could be prevented with thiamine. ${ }^{1}$

Acknowledgements We would like to thank Dr Lisa Rucker (General Internal Medicine, Jacobi Medical Center, New York, USA) for kind English correction of this manuscript.

Contributors $\mathrm{KI}$ wrote manuscript and collected data. TH contributed to formulate idea of manuscript and editing. HY wrote manuscript and edited data. MK contributed to overall writing.

Funding The authors have not declared a specific grant for this research from any funding agency in the public, commercial or not-for-profit sectors.

Competing interests None declared.

Patient consent for publication Obtained.
Provenance and peer review Not commissioned; externally peer reviewed.

\section{ORCID iD}

Mitsuyo Kinjo http://orcid.org/0000-0002-8342-230X

\section{REFERENCES}

1 Sinha S, Kataria A, Kolla BP, et al. Wernicke Encephalopathy-Clinical pearls. Mayo Clin Proc 2019;94:1065-72.

2 Donnino MW, Vega J, Miller J, et al. Myths and misconceptions of Wernicke's encephalopathy: what every emergency physician should know. Ann Emerg Med 2007:50:715-21.

3 Alizadeh L, Mostafavi Z, Jahanshahi A, et al. Wernicke encephalopathy following gastrojejunostomy: a case report and review of the literature. Turk J Emerg Med 2019;19:154-6.

4 Scalzo SJ, Bowden SC, Ambrose ML, et al. Wernicke-Korsakoff syndrome not related to alcohol use: a systematic review. J Neurol Neurosurg Psychiatry 2015;86:jnnp-2014309598.

5 Oudman E, Wijnia JW, van Dam M, et al. Preventing Wernicke encephalopathy after bariatric surgery. Obes Surg 2018;28:2060-8.

6 Isen DR, Kline LB. Neuro-Ophthalmic manifestations of Wernicke encephalopathy. Eye Brain 2020;12:49-60.

7 Zuccoli G, Santa Cruz D, Bertolini M, et al. Mr imaging findings in 56 patients with Wernicke encephalopathy: nonalcoholics may differ from alcoholics. AJNR Am J Neuroradiol 2009;30:171-6.

Copyright 2021 BMJ Publishing Group. All rights reserved. For permission to reuse any of this content visit https://www.bmj.com/company/products-services/rights-and-licensing/permissions/

BMJ Case Report Fellows may re-use this article for personal use and teaching without any further permission.

Become a Fellow of BMJ Case Reports today and you can:

- Submit as many cases as you like

- Enjoy fast sympathetic peer review and rapid publication of accepted articles

- Access all the published articles

- Re-use any of the published material for personal use and teaching without further permission

\section{Customer Service}

If you have any further queries about your subscription, please contact our customer services team on +44 (0) 2071111105 or via email at support@bmj.com.

Visit casereports.bmj.com for more articles like this and to become a Fellow 